\title{
Effect of corporate governance on the financial performance of OMRAN Company
}

\author{
Rehab Masoud AlKhusaibi \\ Dr. Nupur Goel
}

\author{
Middle East College
}

\begin{abstract}
This research study focuses on the Effect of corporate governance on the financial performance of OMRAN Company, the purpose is that any reader should gain a comprehensive idea of the research by knowing more information about the effect of corporate governance on the financial performance of OMRAN Company, and know more about the importance of corporate governance for any organisation especially in large organisations. These days, many organisations are focusing on the corporate governance parts in viable and extravagant way to get done with business functions in perfect and complete way. In order to obtain result, the questionnaire was distributed to employees those are working in finance department and responded by 50 employees. The findings of the study highlighted that corporate governance could prevent the failures in the organisation. Hence, it can be declared that the role of corporate governance is much related with the organisations and its significance cannot be regardless in any aspect. In addition this study covers very important information about the work of board, management, and shareholder and how it is managed and facilitated by the corporate governance of the company. In addition corporate governance is helping the organisation to sustain the financial performance. In this research I have reached to an important point which is showing that corporate governance cannot be ignore in anyway and it needs to observe properly.
\end{abstract}

\section{Introduction}

OMRAN Company is considered as one of the companies that have a purpose to push the investment, expansion, and development of the tourism sector in Oman. OMRAN Company was established in 2005, with a main vision of support and diversifies of the economy. The company achieve this by increasing the ability, area, and possibility of tour sector in Oman. The portfolio of OMRAN Company projects, asset management experience and operation experiment embraces the singular part of Oman's culture and legacy, and protects the natural beauty of Oman future descent. Oman is blessed with all the elements to supports the growing section of tourism. In addition offering amazing vistas and wealthy educational tradition, as a peaceable and unique goal, sectional and global benefit in Oman as a touring purpose continues to earn momentum. The company have an assured track record of transfer tourism and linked projects to world-class standard, and that because of their philosophy of sustainability, limpidity and sharing with famous sectional and global investors. Corporate governance means the collection of operations, mechanisms and relations by which firms are controlled and operated. In addition it is the system of basics, practices and also processes that companies is directed and planned. Basically corporate governance includes balancing the interest of the company's stakeholders, which are: management, customer, suppliers, financiers, government and society. Corporate governance is about running the organisation in a way that warranty it owners as stakeholders are receiving fair return on the investment. In addition it is the operation of a worthy circle that is linking the shareholders to the board, staff, customer, management, and also to the society at large (Clarkson, 1997).

There are many benefits of corporate governance to include the ethical uprightness among company workforce and it can be calculated to protect the resources and entitlements all stakeholders. In addition it develops the dependability of investing public and pulls the strange investors to the companies in specific and economy in general. Corporate governance boosts the 


\section{Journal of Student Research}

Fourth Middle East College Student Research Conference, Muscat, Sultanate of Oman

performance and assure the conformance of the corporate to inspire and preserve a business environment that push managers and contractor to maximize company operational efficiency, returns on development and long-term productivity growth (Akinboade, 2003). Moreover it is very important to have a good relationship between employees inside the organisations, because the work in the organisation depends on the communication and honesty which is between them. The main problem in many organisations arises with the relationship of principal and factor relationships and a various process of director than the shareholders (Farinha, 2003).

As per the study conducted by Mishra and Suar (2010), the corporate governance structure of the company affects the ability to firms to respond to the external factors of the organization that directly impacts on the performance of company. Thus, organization those want to perform better relies on the essence of the good corporate governance. According to Giannakakos and Theodora's (2011) the contribution of the organization in good governance tends to influence the various aspects of the social parameters and economies. In addition to this, it has been explained that the corporate governance within the boundaries of organization needs to be effective and vibrant in order to achieve prosper financial growth. As per the study conducted by Jo and Harjoto (2012) the role of the corporate governance within the premises of any organization is very pivotal. It is because the duty of the corporate governance has been based on analyzed the each single activity of the organization in order to identify the issues and challenges and find solution to avoid uncertainty and allow firm to grow in effective and sound manner to raise the importance of corporate governance within the organization.

As per the study conducted by Wang and Sarkis (2013) the standards and principle of the corporate govern has been extracted from the international as well as local rules, regulations, and laws and at the same side also by the code of conduct, ethical practices and positions. However, the corporate governance is the method tends to employed at all the level of firms with an intention to solve the corporate governance issues. The focus of corporate governance is based on the controlling and monitoring the structure of the organization and allows them different ways to handle the situation in safe and sound manner.

As per the study conducted by Wang, Dou and Jia (2016), there is strong relationship exist between the financial performance and corporate governance of organization. In support with above statement it is cited in the study of Chen, Ren and Zhao (2016) that corporate governance of the organization helps in the decision making. The decision making process is comparatively relies on the activities of corporate governance. According to Hamdani (2019), this is currently centering and grasping the idea of the corporate governance. They have been centering this all together lead into the manageable financial development and advancement.

\subsection{Problem of Statement}

The major problem of this research is to find a solution for the unfavourable corporate governance in some companies, and also how this could affect the financial performance of the company. As well as show how important is to have a good relationship between employees in the company.

\section{Objectives}

The main objective of this research is to find the relationship between the corporate governance and the financial performance of OMRAN Company. Further this research will find the impact of corporate governance for the financial performance of OMRAN Company.

\section{Research Methodology}

Both Primary and secondary data were used in this research. Secondary data has been collected 
through journals, Internet and other study material. Primary data has been collected through questionnaire.

\subsection{Data Collection:}

Questionnaire has been developed to collect the perception of OMRAN company's employees regarding impact of corporate governance on the financial performance.

\subsection{Sample Size:}

Data have been collected from 50 respondents from OMRAN Company by using the survey monkey, the analysis will be through graphics and pie charts

\section{Data Interpretation:}

This section will analysis the data collected from the employees of OMRAN Company.

\begin{tabular}{|l|l|l|}
\hline Gender & Number of responses & Percentage \\
\hline Male & 22 & $44 \%$ \\
\hline Female & 28 & $56 \%$ \\
\hline \multicolumn{2}{|l|}{} & \\
\hline Table 1. Gender & Number of responses & Percentage \\
\hline Age Group & $20 \%$ & 10 \\
\hline $21-30$ years & $22 \%$ & 11 \\
\hline $30-35$ years & $26 \%$ & 13 \\
\hline $35-45$ years & $32 \%$ & 16 \\
\hline $45-60$ years & $0 \%$ & 0 \\
\hline 60 and above years & & 0 \\
\hline
\end{tabular}

Table 2. Age of Respondents

As per above table 1, it is showing that $44 \%$ of the responses were male, and $56 \%$ of responses were female. Table 2 shows that around $20 \%$ of the responses ages were around 21-30 years old, and $22 \%$ of the responses age were around 31-35 years old. 


\section{The financial performance in OMRAN Company depends on corporate governance conditions.}

30

20

10

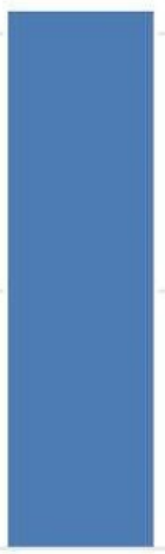

Skipped: 0

Disagree

$8 \%$

4

Strongly disagree

$12 \%$

6

Not sure

$2 \%$

Figure 1. The financial performance in OMRAN Company depends on corporate governance conditions.

As per above analysis figure 1 , it is showing that $36 \%$ of the respondents of the OMRAN Company agreed that the financial performance in OMRAN Company depends on corporate governance conditions; where as $42 \%$ of the employees were strongly agree with this status. In addition $8 \%$ of the responses were disagreeing about the statement and $12 \%$ of the responses were strongly 


\section{Journal of Student Research}

Fourth Middle East College Student Research Conference, Muscat, Sultanate of Oman

disagreeing with this statement. $2 \%$ were not sure about the answer if the financial performance of OMRAN Company depends on the corporate governance conditions or not. 
3. Does corporate governance play an important role in developing the work of the company?

20

15

5

0

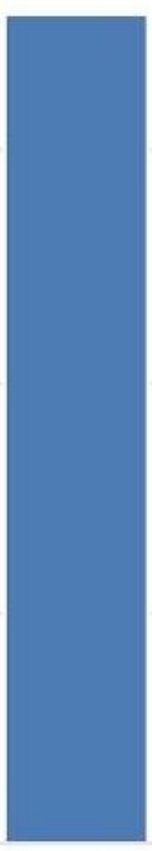

Answered: $50 \quad$ Skipped: 0

Agree

$38 \%$

19

Strongly agree

$36 \%$

18

Disagree

$14 \%$

7

Strongly disagree

$6 \%$

3

Not sure

$6 \%$ 


\section{Journal of Student Research}

Fourth Middle East College Student Research Conference, Muscat, Sultanate of Oman

Figure 2. Does corporate governance play an important role in developing the work of the company?

As per above analysis, we can see that the answers are between agree and strongly agree and many of the employees have chosen the positive answers. 38\% of the responses were agreed that corporate governance play an important role in developing the work of the company. $36 \%$ of the responses were strongly agreed that corporate governance play an important role in developing the work of the company. In addition $14 \%$ of the responses were disagreeing about this statement, and $6 \%$ of them were strongly disagreed. $6 \%$ of the responses were not sure about the statement. 


\section{Do you think there is a positive impact of corporate governance on the performance of OMRAN Company?}

20

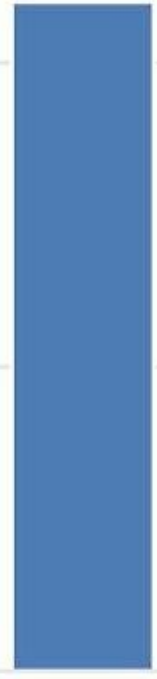

Answered: $50 \quad$ Skipped: 0

Agree

$38 \%$

Strongly agree

$44 \%$

22

Disagree

$8 \%$

4

Strongly disagree

$6 \%$

Not sure

$4 \%$

2 


\section{Journal of Student Research}

Fourth Middle East College Student Research Conference, Muscat, Sultanate of Oman

Figure 3. Do you think there is a positive impact of corporate governance on the performance of OMRAN Company? 


\section{Does corporate governance affect the decision making of OMRAN Company?}

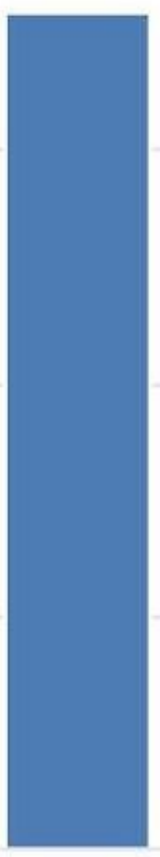

Disagree 


\section{Journal of Student Research}

Fourth Middle East College Student Research Conference, Muscat, Sultanate of Oman

Figure 4. Does corporate governance affect the decision making of OMRAN Company?

As per above figure 4 , it is showing that $34 \%$ of the responses were agreed that corporate governance affect the decision making of OMRAN Company, and 36\% of them were strongly agreed. $8 \%$ of the responses were disagreeing that corporate governance affect the decision making of OMRAN Company, and $12 \%$ of them were strongly disagreeing. $10 \%$ of the responses were not sure about the answer. 
4. Do you think there is a positive impact of corporate governance on the performance of OMRAN Company?

30

20

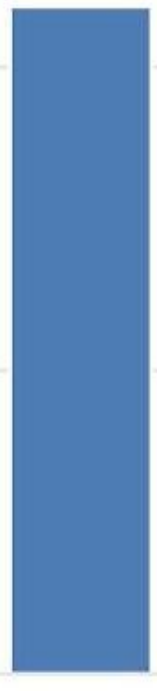

Answered: $50 \quad$ Skipped: 0

Agree

$38 \%$

19

Strongly agree

$44 \%$

22

Disagree

$8 \%$

4

Strongly disagree

$6 \%$

3

Not sure

$4 \%$

2 
Figure 5. Is it true that corporate governance facilitates the work of board, management, and shareholder of OMRAN Company?

As per above analysis, it is showing that $46 \%$ of responses were strongly agreed that the corporate governance play a role in the work of board, management, and shareholder, where as $30 \%$ of them were agree about the statement. On the other hand $10 \%$ of them were not sure, and $8 \%$ were disagreeing. As well as $6 \%$ of the responses were strongly disagree.

\section{Conclusion:}

Corporate governance is setting the rules of thinking, and setting the relationship between several stakeholders in the company from the shareholder to the board to the management. Large companies can develop and reaches their goals by providing several points; one of these important points that they have to provide is good corporate governance. Good corporate governance will lead to have a good financial performance and a good work in general. However it is all depends on the communication between the corporate governance of the company and the employees, where as we can see in small organisation the need of corporate governance becomes less because all the work is managed by the entrepreneur of the company. In addition to manage the work effectively and in way that will increase the profitability of the company you need to have corporate governance.

In conclusion as it was showing that in last 2 years the government has transfer 8 companies to OMRAN, 8 companies with their own boards and management and after this transferred to OMRAN, there was a big need to have a good relationship between OMRAN Company and the other subsidiaries and also to know the dynamics between these subsidiaries board and OMRAN Company board, so corporate governance has set the operating model to decide the relationship between these stakeholders. Clearly it has helped OMRAN Company building to have more visions to know what is happening and it gives the subsidiaries visibility on how to implement the duties. The impact of corporate governance could be indirect but, explaining the relationship this relationship between three layers is considered for OMRAN Company to work and achieve their goals. One of the important roles of corporate governance is setting board operations, as a company OMRAN have to ensure that the company is following the best practices which is set by the CNA board of corporate governance.

\section{Acknowledgements}

I would like to thank to all those are involved in the success of this work. I would like to my supervisor Dr. Nupur goel for motivating and supporting me for this work. I appreciate that she gave me her valuable time.

\section{References:}

Omran.om. (2019) "About Omran" [online] Available from< http://omran.om/omran/about-omran/> [27 Mar 2019]

Investopedia. (2019) "Corporate Governance" [online] Available from<https://www.investopedia.com/terms/c/corporategovernance.asp $>$ [26 Mar 2019]

Alajrami, M. A., and Abu-Naser, S. S. 2017. Onion Rule Based System for Disorders Diagnosis and Treatment. International Journal of Academic Pedagogical Research (IJAPR), 2(8), 1-9.

Al-Malkawi, H.A.N. and Pillai, R., 2018. Analyzing financial performance by integrating conventional governance mechanisms into the GCC Islamic banking framework. Managerial Finance, 44(5), pp.604-623. 


\section{Journal of Student Research}

Fourth Middle East College Student Research Conference, Muscat, Sultanate of Oman

Armstrong \& Larcker, D. F. 2016. Corporate governance, incentives, and tax avoidance. Journal of Accounting and Economics, 60(1), 1-17.

Arora, P. and Dharwadkar, R., 2011. Corporate governance and corporate social responsibility (CSR): The moderating roles of attainment discrepancy and organization slack. Corporate governance: an international review, 19(2), pp.136-152.

Bain, N., \& Band, D. 2016. Winning ways through corporate governance. Springer.

Berger, A. N., Imbierowicz, B., and Rauch, C. 2017. The roles of corporate governance in bank failures during the recent financial crisis. Journal of Money, Credit and Banking, 48(4), 729-770.

Chen, X., Ren, S. and Zhao, Y., 2016. Effects of corporate environmental responsibility on financial performance: The moderating role of government regulation and organizational slack. Journal of cleaner production, 166, pp.1323-1334.

Cuomo, F., Mallin, C., and Zattoni, A.2011. Corporate governance codes: A review and research agenda. Corporate governance: an international review, 24(3), 222-241.

De Han, J., \& Vlahu, R. 2012. Corporate governance of banks: A survey. Journal of Economic Surveys, 30(2), 228-277.

Filatotchev, I. and Nakajima, C., 2014. Corporate governance, responsible managerial behavior, and corporate social responsibility: organizational efficiency versus organizational legitimacy?. Academy of Management Perspectives, 28(3), pp.289-306.

Francoeur, C., Labelle, R., Balti, S. and Bouzaidi, S.E., 2019. To what extent do gender diverse boards enhance corporate social performance?. Journal of Business Ethics, pp.1-15.

Giannarakis, G. and Theotokas, I., 2011. The effect of financial crisis in corporate social responsibility performance. International Journal of Marketing Studies, 3(1), p.2.

Hadani, M. and Schuler, D.A., 2013. In search of El Dorado: The elusive financial returns on corporate political investments. Strategic Management Journal, 34(2), pp.165-181.

Hamdani, Y. and Semuel, H., 2019. Pengaruh Corporate Social Responsibility Terhadap Firm Performance Melalui Intellectual Capital dan Corporate Reputation Sebagai Variabel Mediasi. Petra Business and Management Review, 5(1).

Hassan, R., Marimuthu, M. and Johl, S.K., 2015. Diversity, corporate governance and implication on firm financial performance. Global Business and Management Research, 7(2), p.28.

Ho, F.N., Wang, H.M.D., Ho-Dac, N. and Vitell, S.J., 2019. Nature and relationship between corporate social performance and firm size: a cross-national study. Social Responsibility Journal, 15(2), pp.258-274.

Jo, H. and Harjoto, M.A., 2012. The causal effect of corporate governance on corporate social responsibility. Journal of business ethics, 106(1), pp.53-72.

Karaibrahimoğlu, Y.Z., 2010. Corporate social responsibility in times of financial crisis. African Journal of Business Management, 4(4), pp.382-389.

Kim, K.H., Kim, M. and Qian, C., 2018. Effects of corporate social responsibility on corporate financial performance: A competitive-action perspective. Journal of Management, 44(3), pp.1097-1118. 


\section{Journal of Student Research}

Lunardi, G.L., Becker, J.L., Maçada, A.C.G. and Dolci, P.C., 2014. The impact of adopting IT governance on financial performance: An empirical analysis among Brazilian firms. International Journal of Accounting Information Systems, 15(1), pp.66-81.

Makki, M.A.M. and Lodhi, S.A., 2014. Impact of corporate governance on intellectual capital efficiency and financial performance. Pakistan Journal of Commerce and Social Sciences (PJCSS), 8(2), pp.305-330.

Mishra, S. and Suar, D., 2010. Does corporate social responsibility influence firm performance of Indian companies?. Journal of business ethics, 95(4), pp.571-601.

Murwaningsari, E., 2019. The Relationship of Corporate Governance, Corporate Social Responsibilities and Corporate Financial Performance in One Continuum. Indonesian Management and Accounting Research (IMAR), 9(1), pp.78-98.

Rossi, M., Nerino, M. and Capasso, A., 2015. Corporate governance and financial performance of Italian listed firms. The results of an empirical research. Corporate Ownership \& Control, 12(2), pp.628-643

Singh, S., Tabassum, N., Darwish, T.K. and Batsakis, G., 2018. Corporate governance and Tobin's Q as a measure of organizational performance. British Journal of Management, 29(1), pp.171-190.

Walls, J.L., Berrone, P. and Phan, P.H., 2012. Corporate governance and environmental performance: Is there really a link?. Strategic Management Journal, 33(8), pp.885-913.

Wang, Q., Dou, J. and Jia, S., 2016. A meta-analytic review of corporate social responsibility and corporate financial performance: The moderating effect of contextual factors. Business \& Society, 55(8), pp.1083-1121.

Wang, Z. and Sarkis, J., 2013. Investigating the relationship of sustainable supply chain management with corporate financial performance. International Journal of Productivity and Performance Management, 62(8), pp.871-888. 